\title{
EFFECT OF CUTTING SPEED ON THE PVD-COATED CARBIDE INSERT IN THE MACHINING ON WASPALOY
}

\author{
Yahya Isik ${ }^{1}$ \\ ${ }^{1}$ Uludag University, Vocational School of Technical Science, Bursa, Turkey
}

\begin{abstract}
Waspaloy is a difficult-to-cut material used for gas and steam turbines and aircraft engine components construction that call for considerable strength and corrosion resistance at high operating temperatures. The machining of waspaloy generates high temperatures at the cutting tool edge. The high temperature resulting in the cutting zone critically affects the dimensional accuracy of the job and tool-life of the cutting tool. In this study, the effect of cutting speed on temperature was investigated on tool life and surface quality in the machining on Waspaloy. Experiments were conducted on Waspaloy AMS5708 superalloy samples and a PVD TiAlN-TiN-coated WNVG 080404-IC907 carbide insert was used during the turning process. The highest cutting speed generated higher temperatures. It was concluded that cutting speed the most influencing parameters on chip tool interface temperature and tool life.
\end{abstract}

Keywords: Machining, Waspaloy, Cutting speed, Temperature, Tool life ****

\section{INTRODUCTION}

Nickel based alloy also known as a group of super alloys, is widely used for various parts of components and structure for aerospace, marine, and automobile industries, as well as chemical processing etc. They are used in these aggressive environments because of their ability to maintain high resistance to corrosion, mechanical and thermal fatique, mechanical and thermal shock, creep and erosion at elevated temperatures [1].

Nickel-based alloys exhibit poor machinability owing to their excellent physical properties [2]. These characteristics cause increases in cutting temperature and resultant tool damage, even at low cutting speeds and low feed rates. The machinability of super alloy materials is much more difficult compared to that of steels and stainless steels [3, 4]. Although it is one of the most common nickel superalloys used in the aerospace industry, some drawback are noticed and within these the poor machinability is probably the worst one. Thus, all the cutting parameters, such as tool and coating materials choice, tool geometry, machining strategy, cutting speed, feed rate, depth of cut, lubrication, etc., must be controlled and selected in order to improving quality and surface integrity of the components, increasing productivity and lowering cost [5]. The optimum condition for most machining operations is in the solution treated and partially aged condition where the hardness is about $30 \mathrm{HRC}$ [6].

The machining of Waspaloy generates high temperatures at the cutting tool edge. Tool temperature is very important parameter of metal cutting since it influences tool life, the performance of the tool and surface quality. It is necessary to satisfy the surface technological requirements in terms of high product accuracy, good surface finish and minimum of drawbacks that may arise as a result of possible surface alterations by the machining process [7].
Waspaloy is not easy to cut and thus has been regarded as a difficult-to-cut material. Several problems that exist after machining nickel-based super alloys have been reported in the literature, including surface tearing, plastic deformation, increased surface roughness, and short tool life [8]. The effect of cutting condition and chip-tool interface temperature on attained surface roughness of machined work pieces have been investigated by many researchers. Recent research works are focusing on superalloys as a valuable choice to expedite production process for machined parts. These studies aim to explore the effect of machining parameters on final product qualities. Unfortunately, limited numbers of these researches are available, which they proposed prediction models for machining super alloys [9, $10]$.

The influence of the cutting parameters on the tool temperature was studied among other researches such as Chu and Wallbank in 1998, where a relationship between the cutting temperature and cutting parameters for a specific range of cutting speed and feed rate was established. The correlations for the workpiece temperature with cutting parameters have been developed. The results show that the temperature correlates well with cutting speed and feedrate but the nose radius has little effect [11]. Khan et al., have turning of Inconel 718 using low concentration polycrystalline PCBN inserts. The C-type tools and round tools were compared for built-up-edge (BUE) formation and grooving at different cutting speeds [12]. In summary, the measurement of temperature in machining is still a challenge that requires unique solutions.

In this study, the effect of cutting speed on temperature was investigated on tool life and surface quality in the machining on Waspaloy. Experiments were conducted on Waspaloy AMS5708 superalloy samples and a PVD TiAlN-TiNcoated WNVG 080404-IC907 carbide insert was used during the turning process. 


\section{EXPERIMENTAL PROCEDURES}

\subsection{Experimental Setup}

Round Waspaloy AMS5708 bars of $38 \mathrm{~mm}$ in diameter and $300 \mathrm{~mm}$ in length were used in the experiments. A PVDcoated WNVG 080404-IC907carbide insert was used during the turning process. The cutting insert was indexed and a brand new edge was introduced after each trial. Experimental conditions are shown in Table 1.
The chip-tool interface temperature was measured using an Optris CF4 infrared pyrometer (IR). The accuracy of the system was $\pm 0.3 \%$ for a reading of $+2{ }^{\circ} \mathrm{C}$. Five measurements were recorded by the pyrometer every second. The tool temperature was measured using a K-type thermocouple. The accuracy of the tool temperature measurements using the K-type thermocouple data acquisition system was $\pm 2.5{ }^{\circ} \mathrm{C}$ or $\pm 1 \%$. The thermocouple and IR pyrometer setup is shown in Figure 1.

Table -1: Experimental conditions

\begin{tabular}{|l|l|}
\hline Machine & Harrison M300 \\
\hline Work specimen's materials & Waspaloy AMS5708 superalloys \\
\hline Size & Cylindrical workpieces $\varnothing 38 \times 300 \mathrm{~mm}$ \\
\hline Cutting tool & PVD coated carbide WNVG 080404-IC907 \\
\hline Tool-chip interface temperature & Optris CF4 infrared pyrometer \\
\hline Tool temperature & Type K thermocouples \\
\hline A profilometer & TIME TR200 Surface roughness tester \\
\hline Microscope & Nikon 104 with a magnification of X10 \\
\hline Cutting speed & $45 \mathrm{~m} / \mathrm{min}, 65 \mathrm{~m} / \mathrm{min}, 95 \mathrm{~m} / \mathrm{min}$ \\
\hline Feed rate & $0.10 \mathrm{~mm} / \mathrm{rev}$ \\
\hline Depth of cut & $0.50 \mathrm{~mm}$ \\
\hline Environment & Dry \\
\hline
\end{tabular}

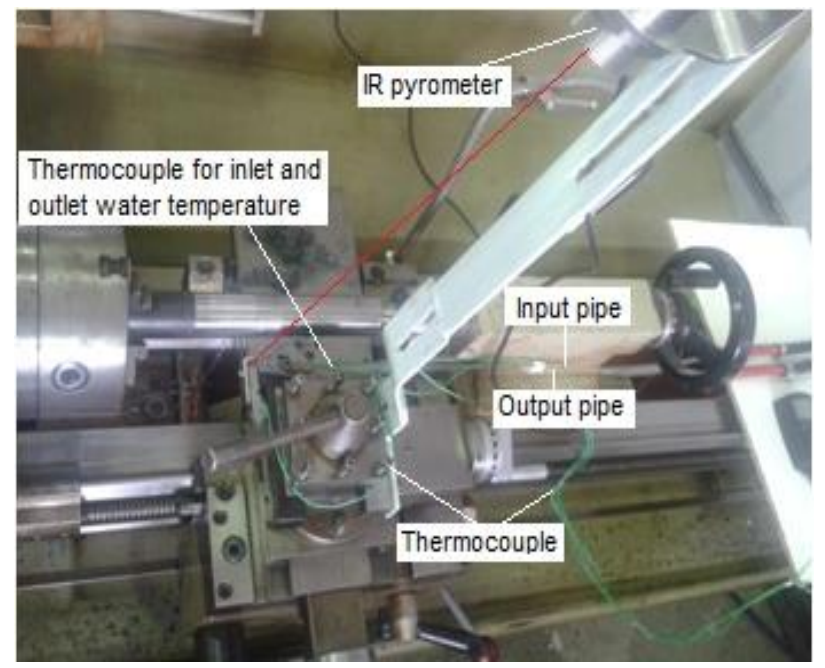

Fig - 1: The thermocouple and IR pyrometer connection in the tool holder

\subsection{Cutting Tools}

Tool coating plays a major role in tool development, especially for dry machining by acting as a partial substitute of cutting fluid. The TiAIN coated carbide tools performed significantly for dry and MQL machining of stainless steel as well as hardened steel up to $63 \mathrm{HRC}$ because of high hot hardness and wear resistance of coating at elevated temperature associated to ultra-fine crystallinity [13].

NR 2020K-08 insert holder, with PVD TiAlN-TiN coated WNVG 080404-IC907 carbide insert was used for the experiments. This type of insert is recommended for
Waspaloy cutting operations. Cutting edge geometry for PVD coated inserts are shown in Figure 2.

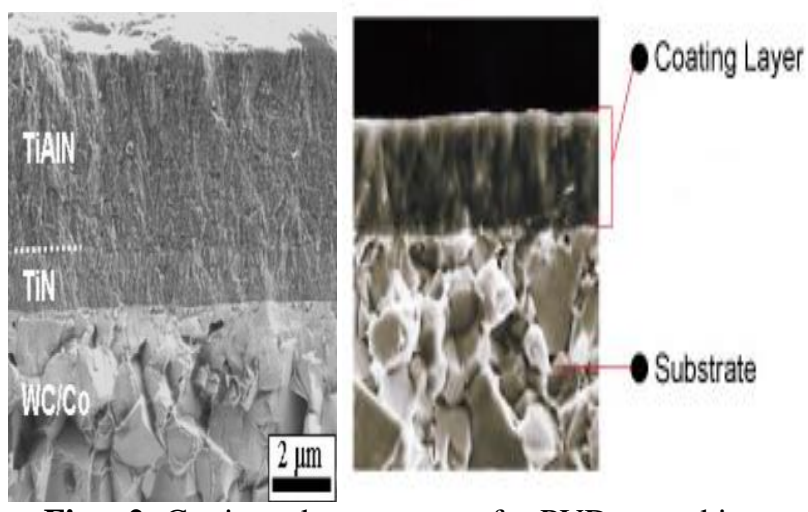

Fig - 2: Cutting edge geometry for PVD coated inserts

\subsection{Workpiece Material}

Nickel-based superalloys currently have hard abrasive carbides in the microstructure that allow the formation of abrasive flank wear [14, 15]. High dynamic shearing strength during the cutting process results in localized shearing stresses. High strength and hardness properties at high temperatures, render the cutting tools undergo deformation due to the cutting process [16]. Chemical composition of Waspaloy - \% volume is shown in Table 2. 
Table- 2: Chemical composition of Waspaloy (Vol.\%) [17]

\begin{tabular}{|l|l|l|l|l|l|l|l|l|l|l|l|}
\hline $\mathrm{C}$ & $\mathrm{S}$ & $\mathrm{Mn}$ & $\mathrm{Si}$ & $\mathrm{Cr}$ & $\mathrm{Mo}$ & $\mathrm{Co}$ & $\mathrm{Ti}$ & $\mathrm{Al}$ & $\mathrm{B}$ & $\mathrm{Zr}$ & $\mathrm{Fe}$ \\
\hline 0.036 & 0.0004 & 0.03 & 0.05 & 19.87 & 4.27 & 13.2 & 3.08 & 1.35 & 0.007 & 0.06 & 0.09 \\
\hline $\mathrm{Cu}$ & $\mathrm{Ni}$ & $\mathrm{P}$ & $\mathrm{Cb}$ & $\mathrm{Ta}$ & $\mathrm{W}$ & $\mathrm{V}$ & $\mathrm{Cb}+\mathrm{Ta}$ & $\mathrm{Ti}+\mathrm{Al}$ & $\mathrm{Ni}+\mathrm{Co}$ & $\mathrm{Y}$ & \\
\hline 0.01 & 57.32 & 0.004 & 0.04 & $<0.01$ & 0.03 & 0.02 & 0.04 & 4.43 & 70.58 & - & \\
\hline
\end{tabular}

\subsection{Experimental Study}

In total, $18(3 \times 3 \times 2)$ combinations of turning trials were carried out to complete the series of cutting experiments. Each test was repeated three times under the same cutting conditions and the average of the measured values was recorded. A series of trials were conducted at different cutting speeds and the surface roughness values were measured using a portable TIME TR200 device. After each turning test, surface roughness was measured at intervals of $120^{\circ}$ on the outer diameter and the average of the values was recorded. The average width of the flank wear $(\mathrm{Vb})$ was adopted as indication of the tool wear. Flank wear was measured using a Nikon104 microscope with a magnification of X10. A workshop microscope with the minimum graduation of $0.01 \mathrm{~mm}$ was used in the measurement.

\section{RESULTS AND DISCUSSION}

Machining hard materials has become an important manufacturing process, particularly in the aerospace and bearing industries. There are many advantages of dry machining such as increased flexibility, decreased cycle times, reductions in machine tool costs, and elimination of environmentally hazardous cutting fluids. To study the behaviour of waspaloy while machining is the main aim of this research. The objectives of this experimental investigation are:

a) To analyze the effect of cutting speed on tool life

b) To assess the effect of cutting speed on chip-tool and tool temperature

c) To analyze the effect of cutting speed on surface roughness and flank wear.

\subsection{Cutting Temperature and Wear}

The highest cutting temperature always occurs at the middle of tool-chip contact area. In this case, maximum heat generated by the experimental value of was $641^{\circ} \mathrm{C}$. Since the tool wear depends largely on the temperature generated, the experimental value proved that this location encountered the most severe flank wear along the cutting edge.

During the cutting process, an increase in the temperature was observed depending on the processing time. This was due to the tool wear and the increased friction at the cutting zone. Moreover, a large amount of the heat was removed from the workpiece by the chip. As the cutting speed increase, more heat was removed. However, the rise in cutting speed increased the temperature abruptly [18]. Therefore, the cutting speed is an important influential factor on tool wears and tool life when cutting nickel-based alloys. In the experiments, the influence of cutting speed on the tool-chip interface and tool temperatures of the Waspaloy samples was observed under dry conditions. The relationship was investigated between the cutting speed and the cutting temperature recorded by the remote temperature measurement method under dry conditions. It was observed that the highest cutting speed generated a higher cutting temperature at the tool-chip interface, which meant that the cutting speed was the most effective parameter. Comparisons of temperatures under the dry cutting conditions are shown in Table 3.

Under dry conditions, the temperature measurement via IR pyrometer indicated that for a speed of $45 \mathrm{~m} / \mathrm{min}$, the maximum temperature was $456{ }^{\circ} \mathrm{C}$. As the cutting speed increased from $45 \mathrm{~m} / \mathrm{min}$ to $95 \mathrm{~m} / \mathrm{min}$, the maximum temperature reached $641{ }^{\circ} \mathrm{C}$, with an increase rate of $28 \%$. A higher cutting speed meant more plastic deformation in the workpiece; therefore, more mechanical energy was converted into heat energy and the temperature increased significantly. Thus, the substantial increase in the temperature was the result of the material characteristics of the Waspaloy.

There is a linear relationship between cutting speed and temperature, even with a low coolant flow rate. A higher temperature difference was obtained at high cutting speeds. Figure 3 and Figure 4 shows the tool-chip interface and tool temperature differences for the dry conditions at various cutting speeds.

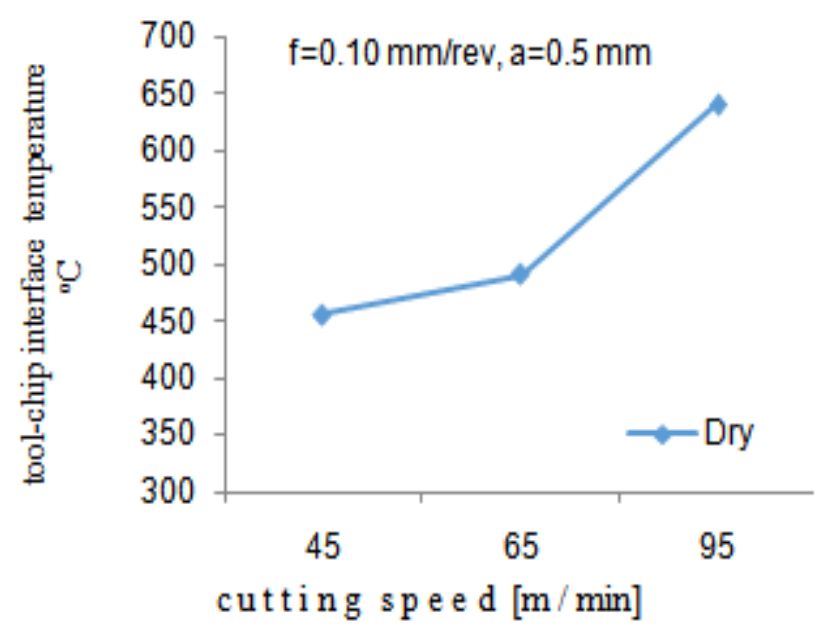

Fig - 3: Tool-chip interface at different cutting speeds 
Table - 3: Comparisons of temperatures under dry conditions $(\mathrm{f}=0.10 \mathrm{~mm} / \mathrm{rev}, \mathrm{a}=0.5 \mathrm{~mm})$

\begin{tabular}{|l|l|l|l|}
\hline & & $\begin{array}{l}\text { Tool-chip interface } \\
\text { temperature }\left({ }^{0} \mathrm{C}\right)\end{array}$ & $\begin{array}{l}\text { Tool } \\
\text { temperature } \\
\left({ }^{0} \mathrm{C}\right)\end{array}$ \\
\hline & $\mathrm{V}(\mathrm{m} / \mathrm{min})$ & Dry & Dry \\
\hline 01 & 45 & 456 & 62 \\
\hline 02 & 45 & 456 & 62 \\
\hline 03 & 45 & 456 & 62 \\
\hline 04 & 65 & 491 & 68 \\
\hline 05 & 65 & 491 & 68 \\
\hline 06 & 65 & 491 & 68 \\
\hline 07 & 95 & 641 & 72 \\
\hline 08 & 95 & 641 & 72 \\
\hline 09 & 95 & 641 & 72 \\
\hline
\end{tabular}

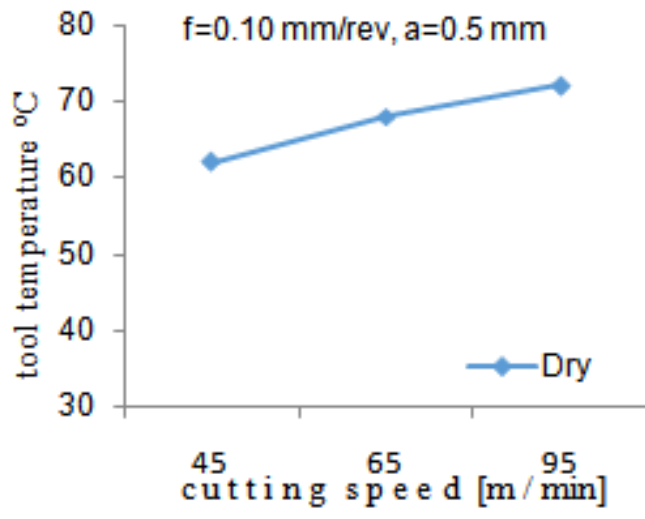

Fig - 4: Tool temperatures at different cutting speeds

\subsection{Tool Wear and Surface Roughness}

The tool wear aspect of tool life is significantly influenced by the temperature generated at the cutting zone, especially for low thermal conductivity alloys such as Waspaloy. When cutting Waspaloy, the most recognisable type of tool wear is the flank wear formed by the cutting speed due to the high thermal combination. The reference flank wear value according to the International Standard Organisation (ISO 3685) of $\mathrm{V}_{\mathrm{B}}=0.3 \mathrm{~mm}$ was chosen as the wear criterion. A cutting tool was rejected and further machining was stopped based upon a combination of the rejection criteria in relation to ISO standard 3685 for tool life testing. The wear mechanism is affected by the cutting temperature; low cutting temperatures can minimize the development of tool wear.

The wear mechanism is affected by the cutting temperature; low cutting temperatures can minimize the development of tool wear. Flank wears and tool life for the dry conditions are shown in Figure 5. The lowest roughness value was shown to be $\mathrm{Ra}=0.699 \mu \mathrm{m}$ at a cutting speed of $95 \mathrm{~m} / \mathrm{min}$, Figure 6. Shows surface roughness comparisons under the dry conditions at various cutting speeds.

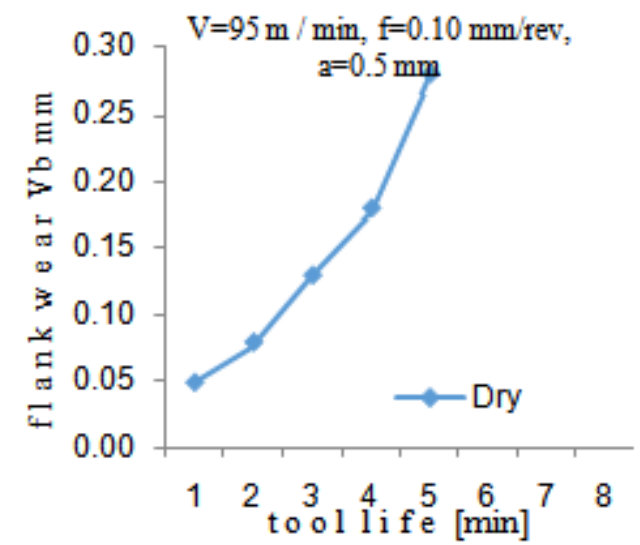

Fig - 5: Comparisons for various cutting speeds on flank wear

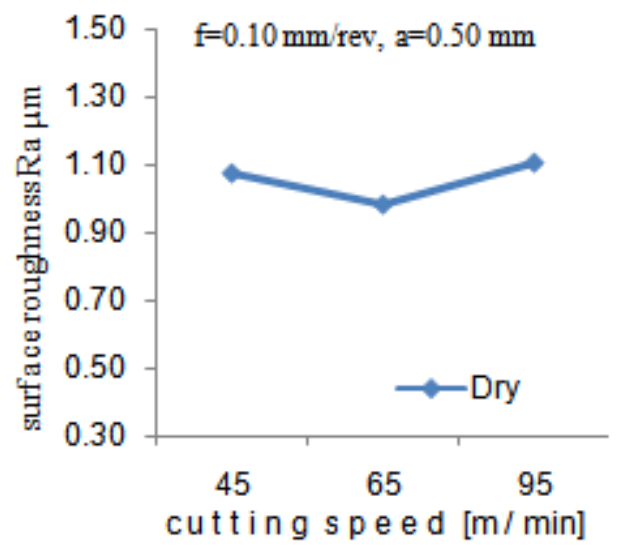

Fig - 6: Comparisons for various cutting speeds on surface roughness

\section{CONCLUSION}

The work material in this experimental study was Waspaloy, which is costly and exhibits poor machinability. The major findings of this work can be summarized as follows:

- The cutting speed is an important influential factor on tool wears and tool life when cutting nickel-based alloys. Higher cutting speed means more plastic deformation in the workpiece owing to the material properties of Waspaloy; therefore, more mechanical energy is converted into heat energy and the temperature increases significantly.

- As the cutting speed was increased from $45 \mathrm{~m} / \mathrm{min}$ to 95 $\mathrm{m} / \mathrm{min}$, the maximum temperature reached was $641{ }^{\circ} \mathrm{C}$, an increase in the temperature rate of about $28 \%$.

- Another important point to be underlined is that the surface roughness is significantly improved when machining at higher cutting speed ranging between 45 and $95 \mathrm{~m} / \mathrm{min}$. This improvement was related to higher temperatures generated at a higher cutting speed, leading to flank wear formation. As the cutting tool became worn, lower surface roughness occurred due to the location of the wear scar, which tended to be away from tailing edge. 


\section{REFERENCES}

[1] Ezugwu, E. O., 2005, "Key improvements in the machining of difficult-to-cut-aerospace superalloys", International Journal of Machine tools and manufacture, 45/12-13, pp. 1353-1367

[2] Kitagawa T, Kubo A, Maekawa K., 1997, "Temperature and wear of cutting tools in high-speed machining of inconel 718 and Ti-6AI-6V-2Sn", Wear, 202, pp. 142-148

[3] Schultz H, Moriwaki T, 1997, "High speeds machining", Ann CIRP, 41, pp. 637-643.

[4] Ezugwu E. O., 2005, "Key improvements in the machining of difficult-to-cut aerospace superalloys", Journal of Machine Tools and Manufacture, 45, pp. 1353-1367

[5] Ulutan, D., Özel, T., 2011, "Machining induced surface integrity in titanium and nickel alloys: A review", International Journal of Machine tools and manufacture, 51/3, pp. 250-280

[6] Varam, S., Rathod, G., 2016, "An experimental investigation on machinability of waspaloy", International Journal of Mechanical and Production Engineering, 4(6), pp. 46-52

[7] Subhash, P. C. B., Rao, C. S. P., 2012, "Modelling and prediction of surface roughness cutting force and temperature while machining Nimonic-75 and nicrofer C-263-super alloys using artificial neural network", International Journal of Mechanical Engineering and Technology, 3(3), pp. 599-613

[8] Dudzinski, D., Devillez, A., Moufki, A., Larrouquère, A., Zerrouki, V., 2004, "A review of developments towards dry and high speed machining of Inconel 718 alloy", Journal of Machine Tools and Manufacture, 44, pp. 439-456.

[9] Horng, J. T., Liu, N. M., Chiang, T., 2008, "Investigating the machinability evaluation of Hadfield steel in the hard turning with Al2O3/TiC mixed ceramic tool based on the response surface methodology", Journal of Materials Processing Technology, 208, pp. 532-541

[10] Lalwani, D. I., Mehta, N. K.., Jain, P. K., 2008, "Experimental investigations of cutting parameters influence on cutting forces and surface roughness in finish hard turning of MDN250 steel", Journal of Materials Processing Technology, 206, pp. 167-179

[11] Chu, T., Wallbank, J., 1998, "Determination of the temperature of a machined surface", Trans. ASME, Journal of Manufacturing Science and Engineering, 120, pp. 259-263

[12] Khan, S. A., Soo, S.L., Aspinwall, D. K., Sage, C., Harden, P., Fleming, M., White, A., Saoubi, R. M., 2012, "Tool wear/life evaluation when finish turning Inconel 718 using PCBN tooling", Procedia CIRP, pp. 283-288.

[13] Arndt, M., 2003, "Performance of new AlTiN coatings in dry and high speed cutting, surface and coating technology", 163-164, pp. 674-680

[14] Ezugwu E. O., Bonney J., Yamane Y., 2003, “An overview of the machinability of aero-engine alloys".
Journal of Materials Processing Technology, 134, pp. 233-253.

[15] Ezugwu, E. O., Bonney, J., Yamane, Y., 2003, “An overview of the machinability of aero-engine alloys", Journal of Materials Processing Technology, 134, pp. 233-253

[16] Products for machining high temp alloy materials, Product Selection Guide No. 204, The Official Website of the Tungaloy Inc. 2010.

[17] Snappy Materials, Commercial Invoice, 34B Barnes Industrial Road South Wallingford CT, 06492 USA

[18] Kus, A., Isık, Y., Cakır, M. C., Coskun, S., Özdemir, K., 2015, "Thermocouple and infrared sensor-based measurement of temperature distribution in metal cutting", Sensor, 15, pp. 1274-1291

\section{BIOGRAPHIES}

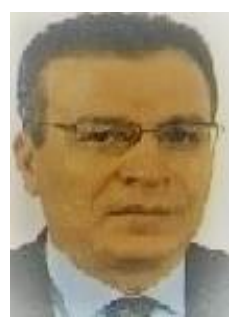

Mr. Yahya ISIK is Associate Professor in Uludag University at the Vocational School of Technical Science, Bursa, Turkey. He received his MSc and PhD in Mechanical Engineering from Uludag University. His main research areas are machinability of materials, Production Techniques, Cutting tools and their performance and Finite element analysis. 